\title{
DISTINCTIONS IN PROTEOMICS AMONG DEVELOPMENTAL STAGES OF DENGUE VECTOR (AEDES ALBOPICTUS) MOSQUITOES
}

\author{
G.M. Saifur Rahman*1, Hamady Dieng, Ahmad Abu Hassan, \\ Uyub Abdul Manaf and M. Rawi Che Salmah \\ School of Biological Sciences, Universiti Sains Malaysia, Gelugor-11800, \\ Penang, Malaysia
}

\begin{abstract}
The embryonic proteomics that drift in the adult stage and responsible for performing visual activities including, biting and maintaining the vectorial life of dengue vector Aedes albopictus is not projected earlier. In a series of experiments we have indicated the concentration and extension of early proteomic cursors in the latter stages of life cycle up to the early emerging adult. We noticed about $70 \%$ gain of protein during larval developmental stages, until pupation. Newly emerged adult mosquitoes lost about $12 \%$ of protein than the pupal stage. In case of peptides, we observed 14-26 polypeptide bands during immature and early adult stages by using $12 \%$ of separating gel in ID SDS-PAGE. The bands in early larval stages up to 4 th instar larvae were in the range of approximately $\sim 58$ to $\sim 7 \mathrm{kDa}$, while in pupal and adult stages they were between $\sim 200$ and $\sim 7 \mathrm{kDa}$. Newly emerged bands in pupal (i and ii) and adult (iii-vi) stages could be identified as stage specific peptides. The band number 10, which migrated at the same position in the PAGE with equal strength in all stages was identified as an essential peptide. Characterization of the above peptides might help in the pin pointing to possible virus transmission blocking mechanism of this vector insect.
\end{abstract}

Key words: Aedes, immature, proteomic profile, protein concentration, pupae, mosquito, dengue vector

\section{INTRODUCTION}

Aedes albopictus (Skuse), a species of Aedine mosquito, which originated in Asia, is increasingly drawing importance as a public health threat as an aggressive biter and a competent vector of at least 23 arbo-viruses including, dengue (Malavige et al. 2004), zika, chikungunya (Delatte et al. 2009), yellow fever and various types of encephalitis viruses (Rosen et al. 1985; Mitchell 1995a,b). It is proven to be a particularly invasive species (Hawley 1988). Its abundance and disease threat have become well established as well as increasing at an alarming rate in most countries around the world because of its ovipositional behaviour (Reiter 1998) and transovarial virus transmission character (Rosen 1987). It survives in a wide range of aquatic habitats, including

*Author for correspondence: <gmsaifur20@yahoo.com>. 1Department of Zoology, National University, Gazipur-1704, Bangladesh

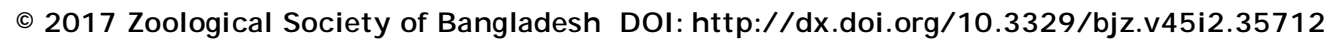


phytolemata, dead leaves on the ground, tree holes, discarded tins, plastic containers, car parts, brick holes and rock pools (Hawley 1988, Sota et al. 1992, Simard et al. 2005).

Efforts to control dengue and dengue vector, multiple initiatives are practicing all over the dengue world. Among them, vaccine experts are trying to find a licensed dengue vaccine, but it is still in the laboratory. Until now, the most practicing weapon to reduce vector population is applying insecticides, but this strategy has proven hazardous, inadequate and ineffective (WHO 1999). Other strategies, like ovitrap, the CDC gravid trap, light trap etc. did not bring that much hope independently in this journey (Reiter 1986, Savage et al. 2008). Thus, integrated control approach is still the mainstay, where genetics based vector control (GVC) approaches are thinking much potential to reduce and replace the infected vector population. As a part of the latest approach, identification of the responsible protein in various biological and physiological functions is very essential.

Furthermore, during the life cycle, mosquitoes pass through different larval and pupal stages. In every stage, they must perform various physiological activities, including digestion, respiration, moulting, etc. In the adult stage, they do a lot of activities, like flying, mating, reproducing and avoiding risks. Most of these physiological activities derived from protein functions. For instance, during blood feeding when temperature rise suddenly, shock proteins help to maintain the three-dimensional integrity of enzymes and proteins and helps mosquitoes to digest ingested blood meals (Karlsson and Wickman 1990, Benoit et al. 2011). Besides, many mosquito proteins are involved in virus transmission and infections have been processed and identified as parts of receptors (Munoz et al. 1998) or co-receptors (Mendoza et al. 2002).

To study detail about the proteins and their expression is known as proteomics, a complement to genomics. It allows the study of the total proteome in an organism, tissue or cell and characterize their functional modifications that cannot be directly determined from DNA or mRNA (Shi and Paskewitz 2006). Protein profiling is widely known and an effective technique for taxonomic study (Onaric and Sumer 2003). Where specific proteome variation within a given taxonomic group or genus is compared by SDS-polyacrylamide gel technique (Thomas and Singh 1992, Navas et al. 2002). One-dimensionalsodium dodecyl sulphate polyacrylamide gel electrophoresis (1D SDS-PAGE) is identified as useful tool for studying protein synthesis in Ae. aegypti and Ae. albopictus in relation to dengue virus infection (Lee et al. 1994, Rohani et al. 2005, Lee et al. 2009). Recently Al-Azab et al. (2013) used this technique to identify the total protein profile of different developmental stages of dengue 
vector Ae. Aegypti. All the above studies did not take into consideration immature stages and newly emerged adult of another important dengue vector Ae. Albopictus mosquito. Therefore, to fill up this gap and to explore its basic proteomic composition, we conducted 1D SDS-PAGE of the developmental stages of immature and newly emerged adult (before feeding anything) of Ae. albopictus mosquitoes.

\section{MATERIAL AND METHODS}

Colonization of mosquitoes: The test samples were collected from a colony reared in the insectarium at the School of Biological Sciences, Universiti Sains Malaysia, Penang. Wild pupae were collected from the outdoor containers in Gelugor, Penang Island. They were identified after emergence according to the standard taxonomic key. The adult Aedes albopictus were separated and reared for the establishment a colony in the laboratory. The colony was maintained according to Saifur et al. (2010) at a room temperature of $29 \pm 3^{\circ} \mathrm{C}$ and a relative humidity of $75 \pm 10 \%$.

Collection of mosquito immature and adults for protein extraction: During immature rearing the early 2nd, 4th instar larvae, pupae and freshly emerged adults were collected. The adults were knocked down in a container containing ethyl alcohol soaked cotton lump. Then the samples were repeatedly washed with $1 \%$ liquid soap, $1 \%$ Clorox and deionised water for 5, 5 and $10 \mathrm{~min}$, respectively. They were made batches separately in $1.5 \mathrm{ml}$ Eppendorf tube with 10 individuals from each category. Three replicates were prepared for each type of sample. They were stored at $-20^{\circ} \mathrm{C}$ for proteomic study.

Extraction of protein from mosquito samples: The preserved samples of different batches of larvae, pupae and adults were homogenized under ice in 80 ul phosphate-buffered saline (PBS), $\mathrm{pH} 7.4,1000 \mathrm{ml}(\mathrm{NaCl} 8 \mathrm{~g}, \mathrm{KCl} 0.2 \mathrm{~g}$, $\mathrm{Na}_{2} \mathrm{HPO}_{4} 1.44 \mathrm{~g}, \mathrm{KH}_{2} \mathrm{PO}_{4} 0.24 \mathrm{~g}$, adjust to $\mathrm{pH} 7.4$ with $\mathrm{HCl}$ ) with $0.02 \mathrm{mM}$ aqueous solution of PMSF. The extracts were centrifuged at 13,500 rpm for 15 minutes at $4^{\circ} \mathrm{C}$. The supernatant that contained the target protein for the measurement were collected in new Eppendorf tubes and kept at $-20^{\circ} \mathrm{C}$ until usage.

Separation of protein: To perform the tests, we used one-dimensional SDSpolyacrylamide gel electrophoresis with standard methods on the Hoefer Mighty Small II system ( $8 \mathrm{~cm} \times 7 \mathrm{~cm}$ mini gels). The discontinuous system consisting of $5 \%$ acrylamide stacking gel and 12\% acrylamide separating gel was used to separate the proteins from the test samples. Approximately $6 \mu \mathrm{l}(3 \mu \mathrm{g})$ from each sample of preserved supernatant were boiled at $100^{\circ} \mathrm{C}$ for three minutes. Then they were loaded onto the gel. To estimate the molecular weights of the unknown 
proteins, Kaleidoscope Prestained Standards markers (Bio-Rad, Hercules, CA) of $2.5 \mu \mathrm{l}$ were used in each gel run. Electrophoresis conditions were $35 \mathrm{~mA}, 110$ volts for $65 \mathrm{~min}$. The separated protein bands were visualized by Coomassie blue (CB) staining $(0.2 \%$ Coomassie brilliant blue in $50 \% \mathrm{MeOH}$ in water containing $10 \%$ acetic acid for $1.30 \mathrm{hr}$ and de-stained overnight with the solution containing $10 \%$ acetic acid and 10\% methanol).

Determination of protein concentration: Protein concentrations of all types of supernatants of larvae, pupae and adults were quantified in triplicate. Aliquots of the supernatants were used for this purpose. A modification of the Bradford method (Bradford 1976) with a Bio-Rad Electroplate Reader using the kit Endpoint was followed. Absorbencies were read by a Dynatech AM60 micro-plate reader with a $595 \mathrm{~nm}$ filter. Concentrations were expressed as optical densities. The BSA samples diluted in the appropriate homogenization medium $\left(\mathrm{dH}_{2} \mathrm{O}\right)$ were used to construct the standard curves. A six-point standard curve of reduced and oxidized BSA was included with each plate. A single estimate of the egg protein concentration was made by doing an average of the above reading.

Data collection and analysis: The standard errors and mean protein concentrations of different test samples were calculated by using the SPSS 15.1 to find the difference in the protein contents among larval instars, pupae and adult stage. Canon camera (Canon EOS 5D Mark II, Canon, USA) was used to photograph Coomassie blue (CB) gels. After taking the photo, they were modified with Adobe Photoshop software (Adobe Systems Inc., San Jose, CA) and fixed at a contrast of $52 \%$, lightened at of $50 \%$. Band patterns were analyzed visually and assigned according to Prévot et al. (2003). The comparison of the synthesis profiles of high - low molecular weight proteins $(\sim 200-\sim 7 \mathrm{kDa})$ among test samples was based on the detection of at least 13 shared bands. Discrepancies in the band pattern were considered, if observed in at least half of the total replicates. The differences in darkness/lightness between identical bands were taken into account as the dark bands are stronger or highly expressed.

\section{RESULTS AND DISCUSSION}

Quantitative changes of larval to adult protein concentration: The mean amount of protein in different developmental stages varied widely (Fig. 1, Table 1). The lowest content was in the second instar larvae which increased gradually and reached peaked at the early pupal stage then decreased steeply at the newly emerged adults. About $70 \%$ of protein gained during larval development until pupation. Newly emerged adult lost about $12 \%$ of protein than the pupal stage.

Proteomes during immature development: The progressive development of protein patterns among developmental stages of Ae. albopictus is shown in Fig. 2 
and Table 2. The protein bands of each treatment including standard marker are numbered from the top to the bottom of the gel according to their direction of migration. The protein profiles revealed 14-26 conspicuous bands ranging from $\sim 7$ to $\sim 200 \mathrm{kDa}$ in different stages of development. Early larval stage produced a few strong bands which tremendously increased with developmental advancement. Fourth instar larvae and pupae produced a quite higher numbers of bands with higher strength. Newly emerged adults produced more faint bands

Table 1. Concentration of protein during different developmental stages of Ae. albopictus. Values with the same letter do not show a significant difference $(p<0.05)$

\begin{tabular}{lc}
\hline Name of developmental stages & Mean concentration $\pm \mathrm{SE} \mu \mathrm{g} / \mathrm{ml}$ \\
\hline $2^{\text {nd }} \mathrm{IL}^{*}$ & $125.00 \pm 1.15^{\mathrm{a}}$ \\
$4^{\text {th }} \mathrm{IL}$ & $735.33 \pm 2.33^{\mathrm{b}}$ \\
Pupae & $792.33 \pm 1.20^{\mathrm{c}}$ \\
Adult & $580.33 \pm 3.53^{\mathrm{d}}$ \\
\hline
\end{tabular}

*IL= Instar Larvae.

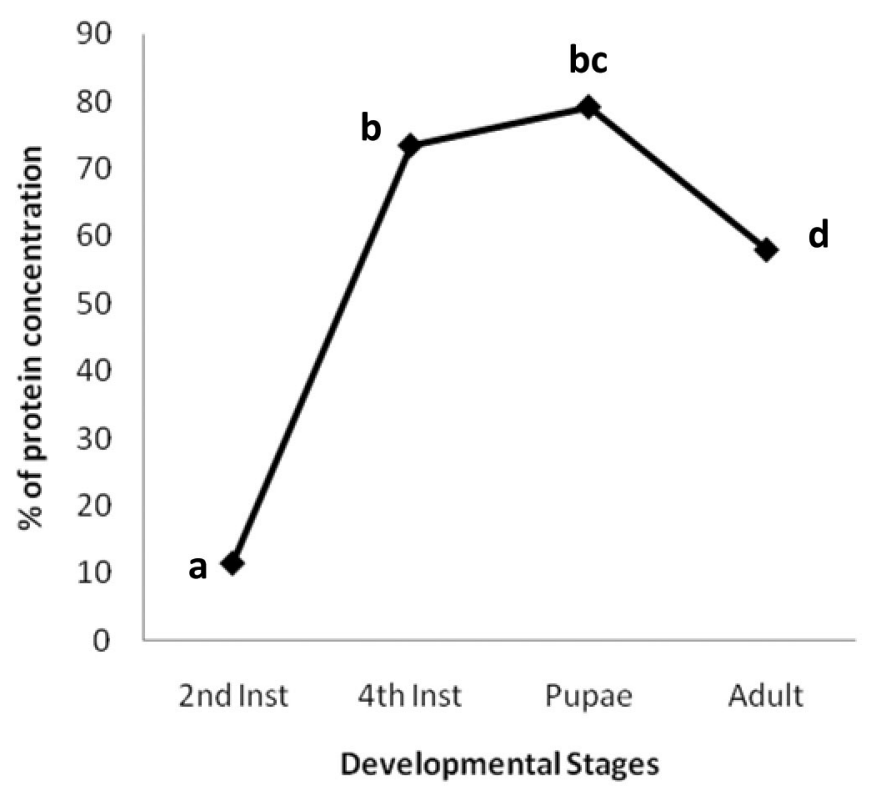

Fig. 1. Change in protein concentrations during immature development of Ae. albopictus mosquito. Values with the same letter are not significantly different $(\mathrm{p}<0.05)$.

together with some new bands (iii-vi) than the previous stage. Bands i and ii were absent in the larval stages those were first appeared in the pupal stage and increased up to iii-vi in the adult stage. Bands 1-7 and 10 were more or less 
present in all stages. While band no. 10 migrated at the same position in the PAGE with equal strength in all stages. Bands 8 and 11-13 were deeply stained in the fourth instars and pupal stages but appeared faint in the second instar larvae and early emerged adults. Band 9 was very much fainted or disappeared in the second instar larvae and adults.

Table 2. Protein profiles (Coomassie blue stained) during immature development of Aedes albopictus mosquito

\begin{tabular}{|c|c|c|c|c|c|}
\hline \multirow[t]{2}{*}{ Band No. } & \multirow[t]{2}{*}{ MW (kDa*) } & \multicolumn{4}{|c|}{ Bands developed in different developmental stages } \\
\hline & & $2^{\text {nd }} \operatorname{Intar} \mathrm{L}^{*}$ & $4^{\text {th }}$ Intar L & Pupae & Adults \\
\hline $\mathrm{i}$ & \multirow{2}{*}{$\sim 200$} & 0 & 0 & ++ & ++ \\
\hline ii & & 0 & 0 & ++ & ++ \\
\hline iii & \multirow{2}{*}{$\sim 112$} & 0 & 0 & 0 & + \\
\hline iv & & 0 & 0 & 0 & + \\
\hline $\mathrm{v}$ & \multirow{3}{*}{$>58$} & 0 & 0 & 0 & + \\
\hline vi & & 0 & 0 & 0 & + \\
\hline 1 & & ++ & ++ & + & + \\
\hline la & \multirow[t]{3}{*}{$\sim 58$} & - & + & + & + \\
\hline $1 b$ & & - & + & + & + \\
\hline 2 & & ++ & ++ & ++ & + \\
\hline $2 a$ & \multirow{3}{*}{$>30$} & + & ++ & ++ & + \\
\hline 3 & & - & ++ & ++ & ++ \\
\hline $3 a$ & & - & ++ & ++ & ++ \\
\hline 4 & \multirow[t]{2}{*}{$\sim 30$} & - & ++ & ++ & + \\
\hline 5 & & - & ++ & ++ & ++ \\
\hline 6 & \multirow{5}{*}{$\sim 25$} & - & ++ & ++ & ++ \\
\hline 7 & & ++ & ++ & ++ & + \\
\hline $7 \mathrm{a}$ & & 0 & ++ & + & + \\
\hline 8 & & 0 & ++ & ++ & + \\
\hline $8 a$ & & 0 & + & + & + \\
\hline 9 & \multirow[t]{4}{*}{$\sim 13$} & 0 & + & - & 0 \\
\hline $9 a$ & & 0 & + & - & 0 \\
\hline 10 & & ++ & ++ & ++ & ++ \\
\hline 11 & & - & ++ & ++ & 0 \\
\hline 12 & $\sim 7$ & - & ++ & ++ & - \\
\hline \multirow[t]{2}{*}{13} & & 0 & ++ & + & - \\
\hline & & 14 & 20 & 22 & 23 \\
\hline
\end{tabular}

*L - Larvae; (++) indicates a very high level of synthesis; (+) indicates a high level of synthesis; $(-)$ indicates a low level of synthesis; (0) indicates a very low level of synthesis or absence of protein.

In our earlier communication, we focused on the association of moisture on the embryonic proteomic profile of Ae. albopictus (Saifur et al. 2014) followed by visualized clarified embryo and spontaneous egg hatching with increasing 
moisture exposure (Saifur et al. 2010). In connection with the previous, this work has indicated the projection of early proteomic cursors in the latter stages of life cycle up to the emergence as an adult that perform all activities in the vectorial life of the mentioned vector mosquito species.
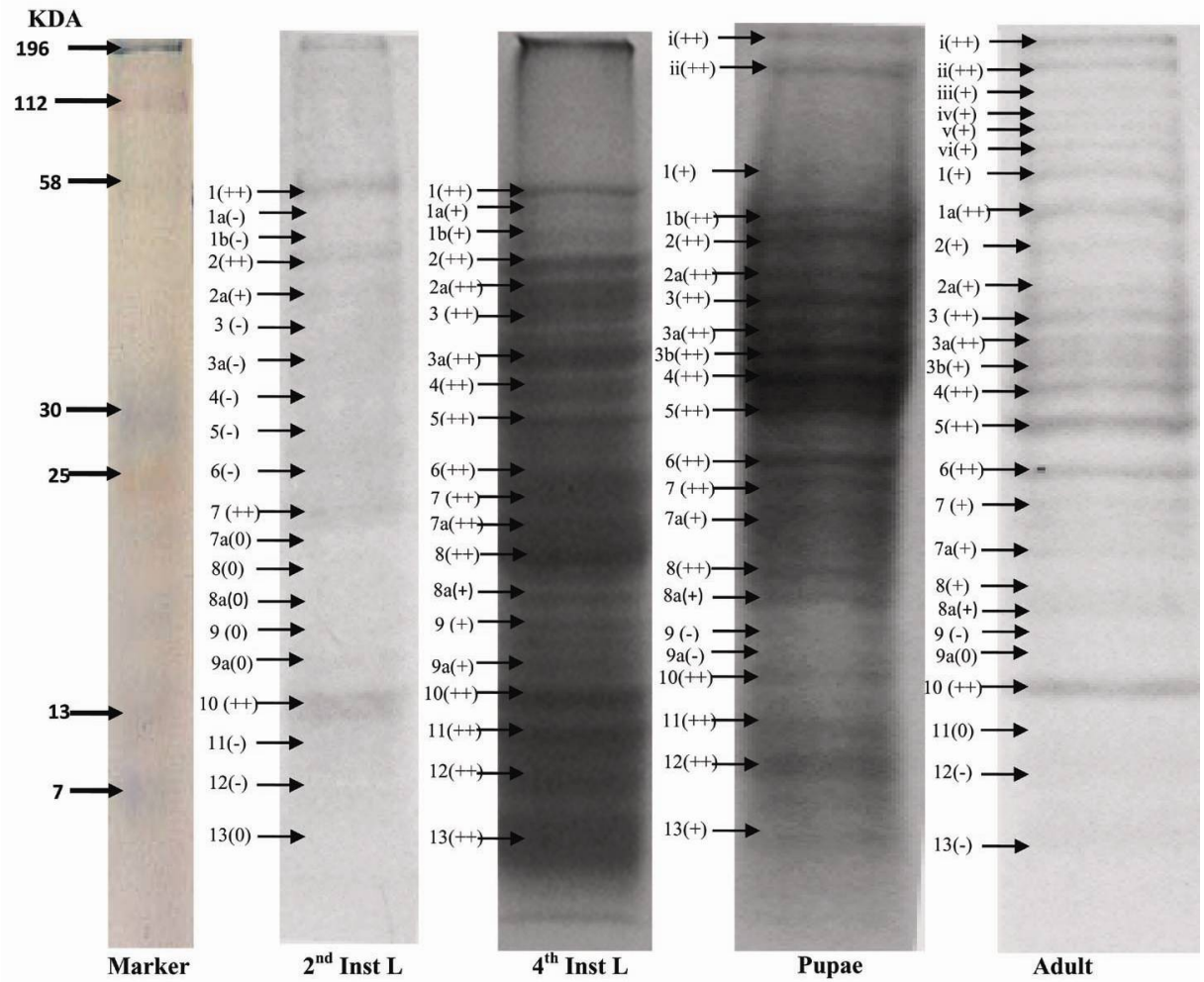

Fig. 2. Comparison in the protein synthesis during immature development of Ae. albopictus mosquitoes; (++) indicates a very high level of synthesis; (+) indicates a high level of synthesis; () indicates a low level of synthesis; (0) indicates a very low level of synthesis or absence of protein.

In general, protein is the essential element of the animal body as well as insect structure. Its higher amount in their body indicates larger body mass, which established higher reproductive success in insects (Santos et al. 1988, Partridge and Fowler 1993), or improved competitive ability (Warren et al. 2006) on life-history traits including disease vulnerability and stress resistance (Lee et al. 2008). Usually, the lowest protein concentration is found in the newly hatched larvae. It increases in later stages (Blevins 1973) with progressive development due to the additional proteins from external food or higher diet in their active feeding period. This additional protein is utilised for organismal growth and addition of new cells. They also perform basic cellular functions and highly specialized functions in higher stages. We observed the proof of this 
continuous higher concentration of protein in higher ages of mosquito immature up to their pupal stage. In this last stage, the protein concentration was the highest due to the complex developments for formation of new organs before emergence, though previous study on Ae. aegypti show the opposite (Blevins 1973). Similar findings were observed in case of blowfly pupae due to the accumulation of cuticular proteins (Ring 1973), pupal size and age (Lang et al. 1965). Srinivasan and Kesavan (1979) correlated the increasing amount of protein concentration in larval and pupal stages of domestic flies with the synthesis of new cuticle, prior to ecdysis and the histogenesis of adult tissue prior to emergence. Chefurka (1965) correlated protein synthesis with activities of cytochrome oxidases in the developing muscles of young adult insects. However, less amount of or a non-significant increase of protein content in the pupal stage indicates its less nutrient uptake in early stages, smaller body size and the consequence activities in this phase.

Furthermore, body size in different stages of mosquitoes immature depends on many factors, including food availability and ideal environmental temperature. In the favourable temperature, the immature get sufficient food due to higher microbial growth in their aquatic habitat and their size become larger with higher amount of protein. The larger immatures produce larger adults. They can complete more gonotrophic cycles and produce more offspring (Saifur et al. 2012). On the contrary, the smaller larvae take comparatively longer time to become pupae and the pupae with less protein, even cannot emerge as adult. Those emerge; they feed frequently to the hosts for getting larger blood meals to fill up their insufficient body protein for running normal physiological activities followed by egg production (Xue et al. 1995). Normally, smaller mosquitoes feed smaller blood meals (1.6 - $2.5 \mathrm{ml})$ than larger females (2.6 - $3.5 \mathrm{ml}$ ) (Klowden and Lea 1978, Klowden and Lea 1979). To get sufficient blood protein for egg production and surviving in the comparatively complex outdoor environment, smaller female mosquitoes show a high frequency of biting (Sheppard et al. 1969, Pant and Yasuno 1973, Trpis and Hausermann 1986, Chadee and Corbet 1991). However, the present study was conducted in a place where the environmental temperature is very conducive for good health of insect immature that may have the role in the higher concentration of protein in the pupal stage.

In case of the proteomic profile in different stages of Ae. albopictus immature, we found more than 13 polypeptide bands by using $12 \%$ of separating gel. The number of protein bands increased with the progressive development. The number of lower $\mathrm{kDa}$ bands decreased and higher $\mathrm{kDa}$ bands increased in the latter stages. In the larval stages the highest band was MW 60 
$\mathrm{kDa}$, while in pupal stage two extra bands with a higher MW 200 kDa was observed. The highest number of bands appeared in the fourth instar larvae with a lower molecular weight suggest that there were different kinds of enzyme related with feeding activities added or generated. There were some new polypeptides appeared during pupal stage, which can be explained as the non functional cells in larval stage become functional in pupal stage and secrete different kinds of enzymes and proteins to make many organs necessary for emergence as adult. Moreover, pupae covered them with a cuticular cage enriched with many proteins, including cuticle degrading proteases (Brookhart and Kramer, 1990) and chitinases enzymes (Fukamizo and Kramer 1985, Koga et al. 1992). They were secreted by the epidermis as an inactive precursor (Locke and Krishnan 1973, Koga et al. 1989) and become activated in the moulting fluid (Samuels and Reynolds 1993, St. Leger et al. 1986).

Regarding the basic proteomic profile of adult dengue vectors, we considered newly emerged unfed Ae. albopictus mosquitoes for our study to avoid unwanted or extra proteins that fed adult mosquitoes get from different hosts with their blood meals (Rohani et al. 2005). We found 7 more bands than the immature stage (Saifur et al. 2014) within the range of MW $\sim 60$ to $\sim 200 \mathrm{kDa}$. The bands with lower MW seen in the immature stage were reduced or fainted in the higher developmental stage. In the living organisms, new proteins are made according to the direction of genes in cells to perform higher activities for survival. Adult mosquitoes do a lot of activities to fight with the environment for their survival including searching blood meals, performing oviposition activities, maintaining flight muscles. Many proteins are involved to perform these activities. The adult mosquitoes produce these necessary proteins with the help of external food i.e., blood meal by the precursor existing in the structural cells (Pan et al. 1969, Hagedorn and Judson 1972, Hagedorn et al. 1975, Benoit et al. 2011). However, our identified major bands in adult mosquitoes might be the key proteins to govern vectorial functions. In the same way, the stage specific proteins observed in different stages might have the controlling functions on moulting as well as emergence. Therefore, it is necessary to identify those proteomes to reduce the pupal emergence and control of vector population.

Furthermore, since proteomic profiling is the direct reflection of the gene expression and helps in understanding the gene regulation. So, their characterization or expression profile is needed for further pin pointing the possible virus transmission blocking mechanism or to modify the function of these proteins to reduce the vectorial fitness of the test species in further studies. 
Acknowledgments: This work was supported by a "Long Term Research Grant (LTRG) for Infectious Diseases, 2011-2014, Ministry of Higher Education, Malaysia and USM (303/Pbiology/650575/U112)".

\section{LITERATURE CITED}

AL-AZAB, A.M., AL-GHAMDI, K.M., SHAHEEN, M.A. and ZAITUON, A.A. 2013. Protein analysis of dengue fever vector Aedes aegypti, using SDS-PAGE in Jeddah Governorate-Saudi Arabia. Biosci. Biotech. Res. Asia. 10: 89-94.

BENOIT, J.B., LOPEZ-MARTINEZ, G., PATRICK, K.R., PHILlIPS, Z.P., KRAUSE, T.B. and DENLINGER, D.L. 2011. Drinking a hot blood meal elicits a protective heat shock response in mosquitoes. Proc. Natl. Acad. Sci. 108: 8026-8029.

BLEVINS, R.D. 1973. Cellular quantity of protein and RNA during development of Aedes aegypti (Diptera: Culicidae). Ann. Entomol. Soc. Am. 66: 373-378.

BRADFORD, M.M. 1976. A rapid and sensitive method for the quantitation of microgram quantities of protein utilizing the principle of protein-dye binding. Anal. Biochem. 72: 248-254.

BROOKHART, G.L. and KRAMER, K.J. 1990. Proteinases in molting fluid of the tobacco hornworm, Manduca sexta. Insect Biochemistry 20: 467-477.

CHADEE D. and CORBET, P. 1991. The gonotrophic status of female Aedes aegypti (L.) over night at the oviposition site (Diptera: Culicidae). Ann. Trop. Med. Parasitol. 85: 461-466.

CHEFURKA, W. 1965. Intermediary metabolism of nitrogenous and lipid compounds in insects. The physiology of Insecta, 3: 59-60, In M. Rockstein [ed.] The Physiology of Insecta, vol. 52Academic Press, New York. 640 p.

FUKAMIZO, T. and KRAMER, K.J. 1985. Mechanism of chitin hydrolysis by the binary chitinase system in insect moulting fluid. Insect Biochemistry 15: 141-145.

HAGEDORN, H.H. and JUDSON, C.L. 1972. Purification and site of synthesis of Aedes aegypti yolk proteins. J. Expt. Zool. 182: 367-377.

HAGEDORN, H.H., O'CONNOR, J.D., FUCHS, M.S., SAGE, B., SCHLAEGER, D.A. and BOHM, M.K. 1975. The ovary as a source of alpha-ecdysone in an adult mosquito. Proc. Natl. Acad. Sci. 72 : 3255-3259.

HARWOOD, R.F. and HORSFALL, W.R. 1959. Development, structure, and function of coverings of eggs of floodwater mosquitoes. III. Functions of coverings. Ann. Entomol. Soc. Amer. 52: 113-116.

HARWOOD, R.F. and HORSFALL, W.R. 1959. Development, structure, and function of coverings of eggs of floodwater mosquitoes. III. Functions of coverings. Ann. Entomol. Soc. Amer. 52:113-116.

HAWLEY, W.A. 1988. The biology of Aedes albopictus. J. Amer. Mosq. Control Assoc. Suppl. 1:1-40.

KARLSSON, B. and WICKMAN, P.O. 1990. Increase in reproductive effort as explained by body size and resource allocation in the speckled wood butterfly, Pararge aegeria (L.). Funct. Ecol. 4: 609617.

KLOWDEN, M.J. and LEA, A.O. 1978. Blood meal size as a factor affecting continued host-seeking by Aedes aegypti (L.). Amer. J. Trop. Med. Hyg. 27: 827-831.

KLOWDEN, M.J. and LEA, A.O. 1979. Humoral inhibition of host-seeking in Aedes aegypti during oocyte maturation. J. Insect Physiol. 25: 231-235. 
KOGA, D., FUJIMOTO, H., FUNAKOSHI, T., UTSUMI, T. and IDE, A. 1989. Appearance of chitinolytic enzymes in integument of Bombyx mori during the larval-pupal transformation. Evidence for zymogenic forms. Insect Biochemistry 19: 123-128.

KOGA, D., FUNAKOSHI, T., MIZUKI, K., IDE, A., KRAMER, K.J., ZEN, K.C., CHOI, H. and MUTHUKRISHNAN, S. 1992. Immunoblot analysis of chitinolytic enzymes in integument and molting fluid of the silkworm, Bombyx mori, and the tobacco hornworm, Manduca sexta. Insect Biochem. Mol. Biol. 22: 305-311.

LANG, C.A., LAU, H.Y. and JEFFERSON, D.J. 1965. Protein and nucleic acid changes during growth and aging in the mosquito. Biochem. J. 95: 372-377.

LEE, H.L., MURAHWA, F.C., GAN, S.C. and NASURUDDIN, A. 1994. Protein profiles of Malaysian Aedes aegypti and Anopheles maculatus and their characterization. Trop. Biomed. 11: 155-155.

LEE, H.L., WONG, Y.C. and ROHANI, A. 2009. Protein profiles of dengue-infected Aedes aegypti (L). Dengue Bull. 33: 115-123.

LEE, K.P., SIMPSON S.J. and WILSON K. 2008. Dietary protein-quality influences melanization and immune function in an insect. Funct. Ecol. 22: 1052-1061.

LOCKE, M. and KRISHNAN, N. 1973. The formation of the ecdysial droplets and the ecdysial membrane in an insect. Tissue Cell 5: 441-450.

MENDOZA, M.Y., SALAS-BENITO, J.S., LANZ-MENDOZA, H., HERNÁNDEZ-MARTÍNEZ, S. and DEL ANGEL, R.M. 2002. A putative receptor for dengue virus in mosquito tissues: localization of a 45-kDa glycoprotein. Am. J. Trop. Med. Hyg. 67: 76-84.

MITCHELL, C.J. 1995a. Geographic spread of Aedes albopictus and potential for involvement in arbovirus cycles in the Mediterranean basin. J. Vector Ecol. 20: 44-58.

MITCHELL, C.J. 1995b. The role of Aedes albopictus as an arbovirus vector. Parassitologia 37: 109-113.

MUÑOZ, L.M., CISNEROS, A., CRUZ, J., DAS, P., TOVAR, R. and ORTEGA, A. 1998. Putative dengue virus receptors from mosquito cells. FEMS Microbiol. Lett. 168: 251-258.

NAVAS, A., LO`PEZ, J.A., ESPA`RRAGO, E., CAMAFEITA, E. and ALBAR, J.P. 2002. Protein variability in Meloidogyne spp. (Nematoda: Meloidogynidae) revealed by two-dimensional gel electrophoresis and mass spectrometry. J. Proteome Res. 1: 421-427.

ONARICI, G. and SUMER, S. 2003. Protein and DNA in Systematic Biology. Turkish J. Biol. 27: 4755.

PAN, M.L., BELL, W.J. and TELFER, W.H. 1969. Vitellogenic blood protein synthesis by insect fat body. Science 165: 393-394.

PANT, C.P. and YASUNO, M. 1973. Field studies on the gonotrophic cycle of Aedes aegypti in Bangkok, Thailand. J. Med. Entomol. 10: 219-223.

PARTRIDGE, L. and FOWLER, K. 1993. Responses and correlated responses to artificial selection on thorax length in Drosophila melanogaster. Evolution 47: 213-226.

PRÉVOT, G.I., LAURENT-WINTER, C., RODHAIN, F. and BOURGOUIN, C. 2003. Sex-specific and blood meal-induced proteins of Anopheles gambiae midguts: analysis by two-dimensional gel electrophoresis. Malar. J. 2: 1-7.

REITER, P. 1986. A standardized procedure for the quantitative surveillance of certain Culex mosquitoes by egg raft collection. J. Am. Mosq. Control Assoc. 2: 219-221. 
REITER, P. 1998. Aedes albopictus and the world trade in used tires, 1985-1995: the shape of things to come. J. Am. Mosq. Control Assoc. 14: 83-94.

RING, R.A. 1973. Changes in dry weight, protein, and nucleic acid content during diapause and normal development of the blowfly, Lucilia sericata. J. Insect Physiol. 19: 481-494.

ROHANI, A., YULFI, H., ZAMREE, I. and LEE, H. 2005. Rapid detection of chikungunya virus in laboratory infected Aedes aegypti by reverse-transcriptase-polymerase chain reaction (RT-PCR). Trop. Biomed. 22: 149-154.

ROSEN, L. 1987. Sexual transmission of dengue viruses by Aedes albopictus. Amer. J. Trop. Med. Hyg. 37: 398-402.

ROSEN, L., ROSEBOOM, L.E., GUBLER, D.J., LIEN, J.C. and CHANIOTIS, B.N. 1985. Comparative susceptibility of mosquito species and strains to oral and parenteral infection with dengue and Japanese encephalitis viruses. Amer. J. Trop. Med. Hyg. 34: 603-615.

SAIFUR, R.G.M., DIENG, H., HASSAN, A.A., MANAF, U.A. and SALMAH, M.R.C. 2014. Proteomic profile during embryonic development of dengue vector Aedes albopictus mosquito. Biosci. Biotech. Res. Asia. 11: 1227-1234.

SAIFUR, R.G.M., DIENG, H., HASSAN, A.A., SALMAH, M.R.C., SATHO, T., MIAKE, F. and HAMDAN, A. 2012. Changing domesticity of Aedes aegypti in northern peninsular Malaysia: reproductive consequences and potential epidemiological implications. PLOS ONE 7(2): e30919. doi: 10.1371/journal.pone.0030919.

SAIFUR, R.G.M., DIENG, H., HASSAN, A.A., SATHO, T., MIAKE, F., BOOTS, M., SALMAH, M.R.C., JAAL, Z. and ABUBAKAR, S. 2010. The effects of moisture on ovipositional responses and larval eclosion of Aedes albopictus. J. Amer. Mosq. Control Assoc. 26: 373-380.

SAMUELS, R.I. and REYNOLDS, S.E. 1993. Moulting fluid enzymes of the tobacco hornworm, Manduca sexta: Inhibitory effect of 20-hydroxyecdysone on the activity of the cuticle degrading enzyme MFP-1. J. Insect Physiol. 39: 633-637.

SANTOS, M., RUIZ, A., BARBADILlA, A., QUEZAdA-DiAZ, J.E., HASSON, E. and FONTDEVILA, A. 1988. The evolutionary history of Drosophila buzzatii. XIV. Larger flies mate more often in nature. Heredity. 61: 255-262.

SAVAGE, H.M., ANDERSON, M., GORDON, E., MCMIllen, L., COlTON, L., DelOREY, M., SUTHERLAND, G., ASPEN, S., CHARNETZKY, D. and BURKHALTER, K. 2008. Host-seeking heights, host-seeking activity patterns, and West Nile virus infection rates for members of the Culex pipiens complex (Diptera: Culicidae) at different habitat types within the hybrid zone, Shelby County, TN, 2002 J. Med. Entomol. 45: 276-288.

SHEPPARD, P.M., MACDONALD, W.W., TONN, R.J. and GRAB, B. 1969. The dynamics of an adult population of Aedes aegypti in relation to dengue haemorrhagic fever in Bangkok. J. Anim. Ecol. 38: 661-702.

SHI, L. and PASKEWITZ, S. 2006. Proteomics and insect immunity. ISJ. 3: 4-17.

SIMARD, F., NCHOUTPOUEN, E., TOTO, J.C. and FONTENILLE, D. 2005. Geographic distribution and breeding site preference of Aedes albopictus and Aedes aegypti (Diptera: Culicidae) in Cameroon, Central Africa. J. Med. Entomol. 42: 726-731.

SOTA, T., MOGI, M. and HAYAMIZU, E. 1992. Seasonal distribution and habitat selection by Aedes albopictus and Ae. riversi (Diptera: Culicidae) in northern Kyushu, Japan. J. Med. Entomol. 29: 296-304. 
SRINIVASAN, A. and KESAVAN, P.C. 1979. Biochemical characterisation of the development of Musca domestica. Proc. Ind. Acad. Sci. 88: 153-162.

St. LEGER, R.J., COOPER, R.M. and CHARNLEY, A.K. 1986. Cuticle-degrading enzymes of entomopathogenic fungi: Cuticle degradation in vitro by enzymes from entomopathogens. $J$. Invertebr. Pathol. 47: 167-177.

THOMAS, S. and SINGH, R.S. 1992. A comprehensive study of genic variation in natural populations of Drosophila melanogaster. VII. Varying rates of genic divergence as revealed by twodimensional electrophoresis. Mol. Biol. Evol. 9: 507-525.

TRPIS, M. and HAUSERMANN, W. 1986. Dispersal and other population parameters of Aedes aegypti in an African village and their possible significance in epidemiology of vector-borne diseases. Amer. J. Trop. Med. Hyg. 35: 1263-1279.

WARREN, M., MCGEOCH, M.A., NICOLSON, S.W. and CHOWN, S.L. 2006. Body size patterns in Drosophila inhabiting a mesocosm: interactive effects of spatial variation in temperature and abundance. Oecologia 149: 245-255.

WORLD HEALTH ORGANIZATION. 1999. Prevention and control of dengue and dengue haemorrhagic fever: Comprehensive guidelines: WHO, Regional Office for South-East Asia. http://www.searo. who. int/entity/ve; Last Accessed on December 2017.

XUE, R.D., EDMAN, J.D. and SCOTT, T.W. 1995. Age and body size effects on blood meal size and multiple blood feeding by Aedes aegypti (Diptera: Culicidae). J. Med. Entomol. 32: 471-474.

(Manuscript received on 15 November, 2017; revised on 31 December, 2017) 